\title{
Challenges and Opportunities for Women Entrepreneurship in India under Globalisation.
}

\author{
Soni kumari \\ Lecturer B.B.A Department, Ranchi Womens College, Ranchi University.
}

\begin{abstract}
Inspite of forming 50 per cent of the total population of the world women do not own even 1 per cent of the world's property. Their role and contribution in industrialisation has remained unaccounted and unassessed. The lot and the position of women the world over has remained neglected. Their share in business and trade is very low. Though they represent half the humanity, their contribution to leadership and management is much less. According to the UN report women receive 25 per cent less wages than men inspite of the law of equal wages for equal work. Time has come for women to come out of the drudgery of housework and give vent to their creativity and entrepreneurship. Political developments in India have also been responsible for determining the role of women in a changing society. It is an accepted fact that the role of women in national development is a crucial one. Women have an important role to play in synthesising social progress with economic growth of developing countries. Non-aligned and other developing countries have attached a great importance to ensure that women play their full role in the development process. The specific role of women in the economic effort has not yet been clearly defined but the need for "integration of women into development" is being particularly felt by women themselves. With the increase in the number of women getting educated, there is considerable awareness among women to be self-employed and gradually the role of women is changing in the society.
\end{abstract}

\section{Introduction}

Entrepreneurship in Developing Countries

The fourth decade of the twentieth century saw an evolutionary change in the status of men and women in the world. The World War II forced the men-dominated societies the world over, to induce and hand over responsibilities to women out of necessity. Hence the post-World War II decades have witnessed a major and continuing phenomenon in the social, economic, industrial and administrative spheres.

The process of becoming entrepreneur involves learning, unlearning and relearning many things relating to the roles, tasks, functions, responsibilities and problems of entrepreneurs. There has been a rapid increase in the efforts made in the past few years to encourage entrepreneurship in developing countries. They have witnessed the phenomenon of the rapid increase in occupational movement among women as owners of their own business. Currently available statistical data from the USA, Canada, indicate that the percentage of women as owners! managers is continuously increasing since 1945 .

\section{Literature Review}

Women in Life and Work in India

In the Indian context since time immemorial, Indian mythology, folklore and epics have narrated tales of men and women who have either singly or jointly upheld and conformed in an ideal manner the roles defined by the existing social case conduct and tradition. This code was of the Indian agrarian society where right from birth a child was located in hierarchical role in the family system. Each of these roles and relationships within the family was cry stalised with expectations and demands and privileges and duties. This pattern of role definition extended beyond the family and into the community. Centuries of traditional agrarian social norms, rigidified the different role actions of men and women and made them absolute. Women were glorified, if they sacrificed their own goals, denied them selves their legitimate space, ignored their resources for their own growth and continued to live for others. These ideals - continue to exist even today in the twentieth century.

\section{Role Enhancement}

Thus the women carried a sense of being at a disadvantage, of being born as a girl in the family. They carried many an unresolved feelings. The process of socialization for many of these women began in childhood when they were told to adjust, accommodate and be acceptable. Essentially the process com municated to them was that there was no space that was theirs. When the women aspired for new modes of life the demands of the tradition, some real and some assumed out of anxiety and fear left them helpless. They looked upOn their husbands! families to break the pattern or to provide support and encouragement. 
A few women had repeatedly brought into focus the women's feelings of helplessness of being stifled, the dilemma of living for others and having no space for their own being. The 'being' of a women had been mortgaged to traditional culture, while her 'becoming' had been mortgaged to the wishes of her husband/family.

\section{Indian Situation - Statistical Data Problem}

Women make the second largest target group for identification of potential entrepreneurs being slightly less than $50 \%$ of the total population. In India there are 99.4 million women workers in a labour force of 272.84 million. Majority of the women seek work, out of economic necessity, but of these a large number are unable to find employment. Their share in total unemployment (40\%) is higher than their share in the labour force (33\%). According to the 1981 census, there are only 150,000 self employed women, a mere 5.2\% of the total number are self employed, of this a majority are concentrated in low paid, low skilled, low technology and low productivity jobs in the rural and recognised sectors. $90 \%$ ( 79.4 million) women workers are in the rural area as against only $10 \%$ (8.6 million) in urban areas. Only 2.5 million women work in the organised sector, a mere $12.4 \%$ of the total employment.

\section{Need for Women EDP}

The proportion of educated and skilled women in total employment is increasing. Hence expanding employment opportunities both to provide income and to harness the growth potential of educated unemployed women is very important.

Promotion of self-employment of educated women has additional advantage of creating more jobs for desiring uneducated women.

No separate allocation for women's development is made. Action in favour of women is more welfare oriented than development oriented, and no constructive steps are taken $t \&$ lead women towards self-employment! entrepreneurship.

It is estimated that an investment ranging between Rs. 500 - 10,000 can, on an average, generate employment for 2.5 persons and depending on the activity every Rs. 1 lakh of investment can generate jobs for 5 - 27 people.

A package of assistance covering product selection, market information and marketing outlet, training in management was required, to accelerate formation of indigenous enterprise. The success of a programme for promotion of women entrepreneur ship-self depends, to a large extent, on the solid foundations that are laid through preparations of realistic and bold action programmes and on providing necessary organisational framework and to get their financial assistance.

The governmental agencies which are concerned with the training programmes of women and promotion of employment and self-employment avenues for women are the Small Industries Development Organization (SIDO) and its chain of Small Industries Service Institutes (SISI) spread all over the country, the National Extension Training Institute, the Khadi \& Village Industries Commission, the All India Handlooms and Handicrafts Board, the Central Silk Board, the Coir Board, etc. There are also State-level organizations which are involved in this endeavour, the Directorates of Industries in the State Governments, the State Small Industries Development Corporation, State Financial Corporations and the District Industries Centre.

Besides these, there are also National Programmes such as' the Integrated Rural Development Programme which has the objective of lifting the individual families above the poverty line by mobilising institutional credit, organizing training programmes, and taking up a range of activities covering agriculture, animal husbandry, fishery, rural and cottage industries, commercial and service activities, etc.

The national scheme - Training of Rural Youth for Self- Employment known as TRYSEM was introduced with the object of training atleast 2,00,OCO rural youth every year in agriculture and allied sectors and small industries for self employment.

The Nationalised Banks can also play an important role in Promoting self-employment by making available credit facilities at 4 per cent interest to the weaker sections of the community and the disabled persons. Social prestige in any society is closely linked with economic utility of the individual concerned. Unless economic and social importance of women in the society is enhanced vis-a-vis their families, state and nation as a whole, the women would continue to suffer from neglect at national 1evel.

\section{Status of Women Entrepreneurs In India}

Nature has made a division of labour entrusting upon men and women different responsibilities for the betterment of the process of evolution. In this division of labour, the women have been endowed upon with the gift of motherhood and up bringing of the future generation. The women, the mother, has been the symbol of continuity of culture, tradition and religion, being the binding force of the family system. Quality of life has depended upon how well 'or how badly the women have performed this duty of hers. Gradually, women withdrew to the four walls of the home for the care of the children, while man worked outside, forging for food. 
With the advance of science and technology, a certain amount of change has come about. An increasing number of women are wanting to participate in the economic activities of the nation. Thus we find the emergence of women entrepreneurs.

A woman entrepreneur is a person who is an enterprising individual with an eye for opportunities, and an uncanny vision, commercial acumen, with tremendous perseverance and above all a person who is willing to take risks with the unknown because of the adventurous spirit she possesses.

Women entrepreneurs can be divided into three categories :

\section{Entrepreneurs in Large and Medium Sector}

In large and medium sectors, women with educational and professional qualifications, take the initiative and manage the business as well as a man. A woman entrepreneur who has received basic managerial training and educational qualifications, sometimes even an MBA degree, usually may head the medium sector and large units. These women because of their qualifications and other opportunities which are available to them are in a superior position and have a competitive edge over others to set up and manage the units.

\section{Entrepreneurs in the Small Sector}

Those women entrepreneurs who do not have education or any formal training in management, but have developed skills take to small scale industry. They choose that product with which they are familiar i.e. garments, weaving, pickles, dolls and handicrafts. Some have ventured into engineering, electronics, chemicals and pharmaceuticals. Some also make surgical instruments, furniture and pottery.

These women entrepreneurs need in the initial period, certain special privileges to overcome the practical social handicaps they face for being a woman such as attitudinal reluctance of officers, lack of information, and too many formalities that need to be completed.

The third category of women entrepreneurs work in cities and slums to help women with lower means of livelihood. Their is service motivated organization to help economically backward sections. They need Government support in marketing as well as getting finances at a concessional rate for their products. Preferential purchasing policy of government helps such institutions to manufacture and sell to the government items like files, chalk, stationery, etc.

Women in our country always remained a victim of neglect and discrimination and were not allowed to perform their due role in the economic or social life of the society. Recognizing the injustice meted out to women in the past, the architects of our Constitution took special care to guarantee equality of rights and opportunities for women in political and social fields and to specifically prohibit any discrimination particularly in matters of employment, wages and human conditions of work.

The need is now keenly felt that women should also work outside the home for getting better living standards for all. It is in this context, that the question of women entrepreneurs or women's industries has taken a new significance especially when unemployment has become a matter of great concern to all. Better health and decreasing infant mortality is a sufficiently persuasive force for women to come out of their homes. Rapid industrialisation, urbanisation, and soclo-political movements have made a dent in the old pattern.

\section{Objective of the study:}

To analyses the different problems and challenges facing women entrepreneurship in India after independence. To identify, select and motivate potential women entre preneurs and to guide them into becoming successful entrepreneurs.T

$\mathrm{o}$ analyse the available statistical information. And the problems that these entrepreneurs may have encountered.

\section{Methods and Materials:}

The complete research work leading to the paper is based on both systematic and ad-hoc research methods. Under systematic methods researcher will adopt both primary and secondary data. Under secondary data the researcher will consult different relevant books, literature, journals, magazines, newspapers, government documents, internet etc Vis-à-vis problems and challenges. In primary data researcher will meet personally the women entrepreneurs and take interviews.

\section{Role and Contribution of Women Entrepreneurs}

\section{Results and discussion}

Inspite of forming 50 per cent of the total population of the world women do not own even 1 per cent of the world's property. Their role and contribution in industrialisation has remained unaccounted and unassessed. The lot and the position of women the world over has remained neglected. Their share in business and trade is very low. Though they represent half the humanity, their contribution to leadership and management is much less. According to the UN report women receive 25 per cent less wages than men inspite of the law of 
equal wages for equal work. Time has come for women to come out of the drudgery of housework and give vent to their creativity and entrepreneurship. Political developments in India have also been responsible for determining the role of women in a changing society. It is an accepted fact that the role of women in national development is a crucial one. Women have an important role to play in synthesising social progress with economic growth of developing countries. Non-aligned and other developing countries have attached a great importance to ensure that women play their full role in the development process. The specific role of women in the economic effort has not yet been clearly defined but the need for "integration of women into development" is being particularly felt by women themselves. With the increase in the number of women getting educated, there is considerable awareness among women to be self-employed and gradually the role of women is changing in the society.

Entry of women in organised business as entrepreneurs is fairly recent, but women have been contributing to production process since times immemorial by working in cottage industries. It is sad that all their economic efforts remain unacknowledged and unaccounted. Women in India have traditionally been highly esteemed. Indian women enjoyed respect and status since Vedic ages but only during last few centuries they lost the position and have to fight for equality. Though women in India can achieve highest position in any field, majority of them are confined to hearths and homes. In Indian countryside millions of women are engaged in home products or cottage industries combining traditional activity and supplementing income generation. Indian history is replete with stories of courage shown by women who had emerged from their shackles. Much before women's resurgence witnessed in the West, in the twentieth century, the history of India is made notable by the presence of women in large numbers, shouldering high responsibilities in the struggle for freedom and in the quest for national reconstruction. As our late Prime Minister Smt. Indira Gandhi said "No society can go ahead if half of it is not given opportunity. Men themselves cannot achieve their fullest if there is a large part of the population which is not by their side and helping them. It is in the interest of all, that women should be able to play a more positive and more creative role in all spheres nationally and internationally. It is heartening that women have excelled themselves in all branches of human activity in the modern age.

Women have all along participated in outdoor occupation, in the fields and taking part in agricultural activities in the farm tending to cattle and poultry. There have always been some professional working women, using their educational skills for being teachers, doctors, nurses, secretaries, hair-dressers, fashion designers, and the like. However, it was realized that they had to play their role in the economic mainstream of the country. The reason for this change was increase in number of educated women and their desire for economic independence and attainment of a separate identity from traditional patterns. Women are engaged in nontraditional activities which were at one time considered exclusively to be the men's domain. These activities relate to production of straw and mill boards, enzymes, electricals, readymade garments, automobile ancillaries, steering gear, assemblies for tractors, foam blankets, printing of text books, crockeries and refractory materials, etc. Electronic is a growing industry-women entrepreneurs can contribute con siderably to this industry as they are best suited for it, especially in software.

Women entrepreneurs today have their own opinion, are self-assured and able to withstand all risks and are efficient managers. Woman is an entity in her own right. She must have a certain self-confidence. Women are more receptive to new ideas and open to change and more confident of the future without disturbing her pivotal role in the family. She should organise working time with the help of modern technology in such a way as to avoid conflict between time for work and time to family. Secondly, it is convenient for a woman to be in control of a small business. This pattern of working in small business suits her dual roles. It is now more and more realised that the strength of a country is in these small businesses. To be viable they must be financially successful. In our present society, and in spite of equal opportunities for women in our country, women play dual roles: that of housewife and mother and that of business executive. However much some people may deny this, it is a fact; many women plan their lives very skilfully and succeed in filling these dual roles in a smooth and unobtrusive way. The experience gained outside her house enables her to enrich her family relationships through new cut look on tradition in a changing world. By continuously seeking connection with the world of science and culture she can become a better organiser and help to promote growth.

Women should seek qualifications along with economic- resources to keep stride with progress. This will necessitate change in social mores, and development of the "tertiary" sector- to help women acquire skills and equip them to enter the busi ness world, women should be motivated to take up administra tive courses by providing fellowship in close contact with universities, update the general and specific executive and pro fessional qualifications and provide a technical and scientific- orientation for the appropriate solution of pressing social and economic problems.

Equal opportunity and equality before law are essential as the social recognition of women's dedication to work is as much a part of her self-fulfilment as that for man. If we recognise the special roles assigned to women in today's world and work with dedication we can herald a new era. More responsible femaleparticipation in the business world will give fuller expression for the constructive use of technology and science 
so that economies could expand and crises could be solved in a way that will give more job opportunities. Access to technology will. also move women 'from traditional household enterprises $t$ other industries. Commerce, transport, storage and communications are examples of fields which are well within her capabilities. Inherent qualities of patience and perseverance of women help them in dealing with labour and hence labour troubles are rare in enterprises managed by women. Blessed with these- qualities and creative urges women can contribute significantly to economic productivity of the nation.. The Productivity Council through its branches helps entrepreneurs to acquire knowledge- on materials management and other allied productivity subjects. As we go towards the east, we find more and more women taking up employment in different fields from the traditional occupation in agriculture like cutting and harvesting to modern management in sophisticated industries, women are proving their talent and adaptability.

The literacy rate of women was-raised from less than $8 \%$ in 1951 to $25 \%$ in 1981, but it is still very low; and it is because girls do not go to schools that it. brings down our average. The number of literate women has increased fro 14 million to 80 million. There are similar increases in figures for the enrolment of girls in schools and colleges; but as the levels of education rise these numbers decline. Women are simply not being given the education which would help in full realization of their potential. This, in turn, affects the number of women who can become entrepreneurs or provide good material for employment.

Government has been making every effort by giving facilities and exercising persuasion to induce parents to send their daughters in schools. Though such efforts have been successful to some extent, the breakthrough can came only when women :receive equal opportunities along with men Women entrepreneurs have the added responsibility of demonstrating what educated women are capable of. But it is not sufficient that they serve only as examples to others; they must also join, in this task of wider education of persuasion, of motivation. Women entrepreneurs should support schemes for adult education and straining of women, who can afterwards be absorbed in individual concerns.

A woman entrepreneur $\mathrm{h}$ to be aware of new trends in business, apart from being fully equipped with uptodate know ledge of technology and innovations. She has to be open minded to changes in administration, changes in values and ever changing social, human and political situations. She must be alert, adaptive and dynamic to keep the concern going. It is this approach that will bring women into development as partners with independent bargaining power and autonomous social goals.

Women should be given all opportunities indecision making process at all levels and in formulation of plans for development. Their identification will not only be beneficial to women but will also improve social relations. Women entrepreneurs can take lead in bringing ethics in business and human approach in socioeconomic relations and make this world a better place to live. A woman entrepreneur should not think of profit alone. Everyone has some social responsibility. Problems have to be solved by changing social attitudes. Women are not less capable of achievement, but their circumstances are different to those of men. Women entrepreneurs in India who generally come from elite class with a favoured educational and social background, use their economic- lever if they act as model employers. They can help their less-favoured sisters by employing larger number of women workers and setting higher standards of management. They can also help the cause of women by motivating girls and their parents for education and training and by showing how education helps to achieve higher goals. The result of women in their examination performance is superior to boys in the same classes but after higher education, the trend is to acquire degrees and then become fall-outs as far as the production effort and the work force of the nation is concerned. Even among the most educated young girls, the first preference is given to marriage rather than a career, hence women tend to make career decisions later than man. This is largely due also to the fact that job opportunities do not exist in proportion to the demand, and with preference being given to the male work-force, the women forcedly have to retire from the scene. However they sometime make an attempt to become "working wives" in specific situations; when their children are old enough to go to schools, when the budget does not seem to stretch and meet the needs of the family to supplement the family income, then they are motivated.

As eighties have been declared Decade of Women, different organisations should take positive steps for the advancement of women. Women entrepreneurs can contribute to world progress because they represent all that is new in the contemporary world. Women entrepreneurs are leaders of women in industry and therefore should be leaders in giving a new turn to society not only in the developing countries, but even in developed and affluent countries. Women entrepreneurs should try for greater endeavour leading to their achievement.

Most of the small entrepreneurs belong to small and medium sized industry and they provide the nucleus and laboratory for future development.

Women in the Third World are at once the most exploited class and a source for great development potential. Self employment programmes are most ideally suited for them. The exchange of information and cooperation between the women entrepreneurs of the developed and the developing countries can provide impetus to enterprise development among women. The emergence of women in the economic sense as entrepreneurs is a significant development in the emancipation of women and for securing for them a place in the society. Women 
entrepreneurs should make a success of their entreprise and help economic progress of developing and underdeveloped countries. The association of women with economic enterprises should also usher in an era of clean business ethics and would provide a healing touch in promoting peace and amity in the strife ridden world of today.

\section{Conclusion}

List of Projects for Small Business Establishment Suitable for Women Entrepreneurs

Name of the Small Business Manufacturing Industries :Ammonia Printing ,Ball Point Refills,Battery Charging,Book Binding,Chalk Crayons,Circulation Library,Cotton Ropes,Decorative Lighting,Detergent Powder,Flour Mill,Foam Leather Products,Semi-Culture Unit,Papad,Paper Bags,Photo Frames,Photo Studio,Plastic Bangles,Pressed Dry Chana,Printing Press, Readymade Garments Job Work,Salted Peanuts (Khari Sing),Tobacco Box,Tube Vulcanising,Umbrella Assembling,Wax Candles,Aluminium Hangers,Banana Chips,Biscuits,Building Bricks,Canning of Chairs,Card Board Boxes,Cement Jalli,Ceramic Decoration Job Work,chappals and Sandals,Cleansing Powder,Coal Briquettes,Diamond Cutting and Polishing Job Work,Electrical Accessories Repair,Electric Series,File Tags and Shoe Laces,Gas Welding Job Work,G.I. Washers,Glass Toys,Hand Carts,Lime Making,Link Clips and Conduit Saddles,Mandap Decoration,Miniature Lamps,Nepthalene Balls ,Non-ferrous Casting Job Work,Oil Ghani,Paper Cups and Plates,Paper Envelopes,Phenyl,Plaster of Paris Toys,Pop Corn,Potato Wafers,Printed Circuit Board,Rubber Gloves,Saree Falls,Saw Mill Job Work,Soda Water and Work,Spices Grinding,Thread Reels,Transformer for T.V. and Transistors, Trunks and Storage Bins,Tube Light Fittings,T.V. Antenna,T.V. Repair,Vermicalli, Wooden Furniture,Wooden toys, Wrist Watch Crown,Agarbatti,Aluminium Pan (Kadai),Assembly of Bicycle Saddles,Automobile Number Plates,Balm,Batik Printing Job Work,Boot Polish,Confectionery,Dehydration of Potato Chips,Detergent (Soap) Cakes,Dry Cleaning,Glass Beads,Hair Oil,Hand-Made Pencils,Holdall,Kum Kum,Laboratory Glass Equipment,Lemon Squash,Liquor Ammonia,Mango Chunda,Metallic Chains for Animals,Metallic Slates,Mixed Fruit Jam,Mixed Vegetable Pickle,M.S. Hinges, Tower Bolts,Nail Polish,Optical Components,Paint Brushes, Recovery of Silver from Hypo Waste,Regrinding of Knives and other Domestic Cuttei,Sealing Wax,Shampoo,Shikakai Soap,Spectacle Lenses,Sport Nets,Steel Almirahs,Steel Chairs,Stove Pins,Synthetic Syrup,Telcum Powder,Tomato Chilli Sauce,Tomato Ketchup,Tooth Powder,Tuty Fruity,Vaseline,Simple Fabrication,Sports Nets.,Leaf Plates \& Cups,Aluminium Hangers,Bicycle Stands,Petticoat making.Blacksmithy,Wooden Toys,Card-board Boxes,Brassieres,Fan Regulators \& Emergency Light,Transformers \& Chokes and other Domestic Cutter,Rechargeable Torches,Transistorized Radios, Readymade Garments,Battery Eliminator \& Charger,Woollen Garments,Link Clips, Transistor Radio Shop,T.V. Repair Shop,House \& Office Wiring,Rewinding \& Repairing of Electric Motor ,Shoe Repair,Cycle Repairing,Power Driven 'Baan',Power Driven Ghani Marketing Units,Fruit Preservation Units,Leather Sports Goods,Steel Furniture (Blacksmith),Gur Units,Khandsari Units, Wooden Furniture (Carpentry),Lime Kiln Units, Pottery Units,Manufacture of Ban (typical tiny unit),Bhar Bhunja Unit,Manufacture of Tanned Leather,

Village Industries-Scheme for Financing Medium Sized Apiaries in collaboration with Khadi \& Villag Industries Commission (KVIC)

Manufacture of Quick Lime,Papad Making,Manufacture of Soap,Manufacture of Mustard Oil and Cake,Manufacture of Agricultural Implements, Bullock Carts, Building Material \& other Unity furniture,Engineering Workshop,General Merchant Shop,Mashala Unit,Sweet Shop,Radio Shop,Medical Store,Handloom Unit, Carpet Unit.

Microfinance services can be a very useful part of integrated empowerment and poverty alleviation interventions. Contrary to financial self-sustainability orthodoxy, where repayment incentives are built into credit delivery, there is an interesting complementarity of microfinance and other human development and empowerment interventions.

Finally, the microfinance programmes targeting women are often promoted as a component of packages to absorb the shock of structural adjustment programmes and globalisation, with macro economic and social policy prescriptions which seriously disadvantage women, decrease public sector availability of complementary services and remove any existing welfare nets for the very poor. The assumptions of automatic beneficial impacts of microfinance can thus at worst be used as a pretext for withdrawing support for other empowerment and poverty alleviation measures.

The development of an innovative and diversified microfinance sector which makes a real contribution to women's empowerment will require much more commitment from donors than has been the case to date. It is crucial that donors make their commitment to women's empowerment explicit through inclusion of questions on gender policy and empowerment as an integral part of Best Practice guidelines and the criteria for funding. 


\section{Reference}

[1] Buckley, G., "Micro-finance in Africa: is it either the problem or the solution?" World Development $25: 1081$ - $1093,1996$.

[2] CGAP., Micro and Small Enterprise Finance: Guiding principles for selecting and supporting intermediaries. CGAP, 1995.

[3] Goetz, A.M., and R. Sengupta., "Who Takes the Credit? Gender, Power and Control over Loan Use in Rural Credit Programmes in Bangladesh", World Development 24 : 45 - 63, 1996.

[4] Johnson, S., Gender and Micro-finance: guidelines for best practice. Action Aid, UK, 1997.

[5] Kabeer, N., The conditions and consequences of choice: Reflections on the measurement of women's empowerment, UNRISD, 1999.

[6] Mayoux, L., Women's Empowerment and Micro-finance programmes : Approaches, Evidence and Ways Forward, The Open University Working Paper No. 41, 1998a.

[7] Mayoux, L., "Questioning Virtuous Spirals : micro-finance and women's empowerment in Africa", Journal of international Development $11: 957-984,1999$.

[8] Otero, M., and E. e. Rhyne (Ed), The New World of Microenterprise Finance : Building Healthy Financial institutions for the Poor, London : IT Publications, 1994.

[9] Rogaly, B. "Micro-finance Evangelism, 'destitute women' and the hard sel1ing of a new antipoverty formula", Development in Practice $6: 100$ - 112, 1996.

[10] Rosenberg, R, internal Review of UNCDF Micro-finance Activities, CGAP, 1998.

[11] Sebstad, J., Toward guidelines for lower-cost impact assessment methodologies for microenterprise programmes, Management Systems 1nternational, 1998.

[12] Govt. of India, Economic Survey, 1999-2000.

[13] Jayati Ghosh, "Globalization and Women in India; Some Macro Considerations", Proceedings of the Seminar on Globalization and the Women's Movement in India.

[14] Rajput, Pamedt, Globalization and Women, New Delhi, Ashish Publications, 1994.

[15] Siwal, B.R., "Structural Adjustment: Macro Perspective", Social Welfare, 45:1; 1998, 6-8 \& 48.

[16] Vijay Govindarajan and Anil K. Gupta, "Turning Global Presence into global Advantage", in Business Standard Mastering Global Business, Part. II, Nov. 27, 1998, p.4.

[17] Joseph Stiglitz, Making Globalization Work-the Next Step to Global Justice, Allen Lane, Penguin ,Books, England 2008.

[18] Vashishtha B.K: Encyclopeclia of Women in India, Praveen Enclopedia Publications, New Delhi, PP6-17,1976.

[19] Dr. G. Sandhya Rani, Associate Professor, Dept. of Women's Studies, S.P.Mahila Visvavidyalayam, Tirupati - 517 502,Email: sandhya_gudipudi@yahoo.co.in,

[20] Asia-Pacific Journal of Social Sciences, Special Issue No.1, Dec 2010, pp 144-153 153 